\title{
AYURLOG
}

National Journal of Research in Ayurved Science

(A peer-reviewed open access Indexed e-journal of Ayurved Since 2013)

http://www.ayurlog.com

June- 2020 | Volume $08^{\text {th }} \mid$ Issue: $3^{\text {rd }}$

ISSN: $2320-7329$

A Clinical Study of Gridhrasi Managed with Ayurvedic Treatment

\author{
Amruta Jadhav*1', Anil Burley²,Shrikant Deshmukh ${ }^{3}$ \\ PG Scholar ${ }^{1}$, GUIDE and Professor ${ }^{2}$, HOD and Professor ${ }^{3}$ \\ Department of Kayachikitsa, CSMSS Ayurveda Mahavidyalaya, \\ Aurangabad, Maharashtra. \\ *Corresponding author: Email - Amrutajadhav512@gmail.com; Phone No: (+91) 9623857575
}

\section{ABSTRACT: -}

Sciatica is most common musculoskeletal disorder. Affecting the movement of leg is low back pain. It is a pain dominant disease and reduces human activity. It restricts the movement of the affected leg. Gridhrasi can be equated with Sciatica. were Pain, Weakness, Numbness, and other Discomforts along the path of Sciatica nerve often accompanies low back pain. The common symptoms of Gridhrasi is pain starts from Spike and then radiates to Kati, Prushta, Uru, Janu, Jangha, Paad along with Stambha, Ruka, Toda, Spandana and causes Sakatiutkshepa Nighra (restricted movement of lifting of the leg). ${ }^{[1]}$

In Ayurveda Basti Chikitsa is considered to be half chikitsa for vat dosha. So, Katibasti with Bala Tail ${ }^{[2]}$ and Shaman chikitsa was selected for the patient.

KEYWORDS: - $\quad$ Gridhrasi,

Katibasti, Balatail

\section{INTRODUCTION: -}

Pain is the chief cause of visiting a Doctor in most patient. it is known as Ruja which is one of the synonyms of diseases. It disturbs physical and mental status of a patient. Pain is cardinal symptom in most of the Vatavyadhis. Gridhrasi is such Ruja pradhana Vatvyadhi.

Gridhrasi an entity enumerated by Shula Pradhana is one among the 80types of Nanatmaja Vat Vyadhi. $^{[3]}$ In Gridhrasi intense Pricking pain characteristically radiates from Sphika to Pada. 
The sign and symptoms are seen in Gridhrasi can be correlated with Sciatica in modern terminology. Sciatica is very painful condition in which pain begains in lumbar region and radiates along the posterior lateral aspect of thigh and leg. It occurs due to spinal nerve irritation and is characterized by pain in distribution of Sciatica nerve.

Low back pain and radiating pain due to lumbar disc prolapsed are the major cause of morbidity throughout the world. Life time incidence of low back pain is 50$70 \%$ with incidence of Sciatica more than $40 \%$. Sciatica due to lumbar disc prolapsed occurs only in 4-6\% the population.

In reference to Sciatica treatment medical science has only symptomatic management with analgesic like non-steroidal, antiinflammatory drugs in some cases nerve compression is more, surgical procedure like laminectomy, discectomy but this surgical procedure is expensive with their limitation.

Acc. To Charak Stambha, Ruka, Toda, and Spandana are the signs and symptoms of Vataj Gridhrasi. Aruchi, Tandra, and Gaurav are additional symptoms of Vata-kaphaj Gridhrasi.

\section{CASE REPORT: -}

Name of patient - XYZ
Gender - Female

Age - 55 years

Occupation - Housewife

Religion - Hindu

Desh - $\quad$ Sadharan

Marrital status - Married

CHIEF COMPLAINTS: -

1) RUK (pain)

2) STAMBHA (STIFFNESS)

3) SPANDANA (TWITCHING)

4)TODA (PRICKING SENSATION)

\section{CASE HISTORY: -}

A 55yrs old female patient suffered from Low back pain and left sided leg pain with restricted of left leg movement, Sthambha (Stiffness), Spandana (Twitching), Toda (Pricking Sensation). Onset of these symptoms are last from 2 years but from 2 months it got worsen.

Past history: - No any major illness

Family history: - History was noncontributory.

\section{OTHER COMPLAINTS: -}

Tingling numbness. Difficulty in walking

$\mathrm{K} / \mathrm{C} / \mathrm{O}$ - Fissure in Ano

\section{GENRAL EXAMINATION: -}

Pulse rate $-78 / \mathrm{min}$

$\mathrm{BP}-130 / 90 \mathrm{~mm}$ of $\mathrm{Hg}$

Weight $-60 \mathrm{~kg}$

$\mathrm{P} / \mathrm{A}$ - Soft

Liver and Spleen- not palpable S/E - CNS, CVS, RS - No any deformity found. 
ASHTAVIDHA PARIKSHA

1. Nadi $-78 / \mathrm{min}$

2. Shabda - Spashta

3. Mutra - 4-6 times per day

4. Spardha - Ushna

5. Mala - Once a day

6. Druk - Prakrut

7. Jivha - Saam

8. Aakruti - Madhyam

\section{DASHVIDHA PARIKSHA}

- Prakruti-Vat kaphaj

- Vikruti-Dosha-Vat pradhan

- Dushya-Asthi.Sandhi

- Satwa-Madhyam

- Sara-Madhyam

- Samhanana- Madhyam

- Pramana-Prakrut

- Satmya-Sarva Rasa

- Aharshakti-Madhyam

- Vyamashakti-Avaral

- Vaya- 55yrs

GRADATION OF SYMPTOMS: RUK (PAIN)

\begin{tabular}{|l|l|}
\hline 0 & No pain \\
\hline 1 & Occasional pain \\
\hline 2 & $\begin{array}{l}\text { Mild pain but no difficulty in } \\
\text { walking }\end{array}$ \\
\hline 3 & $\begin{array}{l}\text { Moderate pain and slightly } \\
\text { difficulty in walking }\end{array}$ \\
\hline 4 & $\begin{array}{l}\text { Sever pain with sever difficulty } \\
\text { in walking }\end{array}$ \\
\hline
\end{tabular}

STAMBHA (STIFFNESS)

\begin{tabular}{l|l}
0 & No stiffness \\
\hline
\end{tabular}

1 Sometimes for 5-10 min

2 Daily for 10-30min

3 Daily for 30-60 min

4 Daily more than $60 \mathrm{~min}$

\section{SPANDANA (TWITCHING)}

\begin{tabular}{|l|l|}
\hline 0 & No twitching \\
\hline 1 & Occasionally twitching \\
\hline 2 & $\begin{array}{l}\text { Feeling of spandana at standing } \\
\text { position }\end{array}$ \\
\hline 3 & $\begin{array}{l}\text { Feeling of spandana at sitting } \\
\text { position }\end{array}$ \\
\hline 4 & Feeling of spandana at rest \\
\hline
\end{tabular}

TODA (PRICKING SENSATION)

\begin{tabular}{|l|l|}
\hline 0 & No pricking sensation \\
\hline 1 & Occasional pricking sensation \\
\hline 2 & Mild pricking sensation \\
\hline 3 & Moderate pricking sensation \\
\hline 4 & Severe pricking sensation \\
\hline
\end{tabular}

SLR TEST

(STRAIGHT RAISING TEST)

\begin{tabular}{|l|l|}
\hline 0 & More than 70 degree \\
\hline 1 & $51-70$ degree \\
\hline 2 & $30-50$ degree \\
\hline 3 & Less than 30 degree \\
\hline
\end{tabular}

\section{TREATMENT: -}

1. Sarvang Snehan with Abhyanga Taila for 14 days.

2. Sarvang Swedan with Dashmul Kwath for 14days. 
3. Kati basti with Bala Taila for 14 days.

\section{ORAL MEDICATIONS: -}

1. Aampachak vati $250 \mathrm{mg}, 2$ tabs twice a day for first 7 days.

2. Rasna ghana vati $250 \mathrm{mg}, 2$ tabs twice a day for 14 days.

\section{RESULT: -}

\begin{tabular}{|l|l|l|l|}
\hline Symptoms & $\begin{array}{l}\mathbf{0} \\
\text { day }\end{array}$ & $\begin{array}{l}\mathbf{7}^{\text {th }} \\
\text { day }\end{array}$ & $\begin{array}{l}\mathbf{1 4}^{\text {th }} \\
\text { day }\end{array}$ \\
\hline RUK (pain) & 3 & 2 & 2 \\
\hline $\begin{array}{l}\text { STAMBHA } \\
\text { (STIFFNESS) }\end{array}$ & 2 & 2 & 1 \\
\hline $\begin{array}{l}\text { SPANDANA } \\
\text { (TWITCHING) }\end{array}$ & 3 & 2 & 1 \\
\hline $\begin{array}{l}\text { TODA } \\
\text { (PRICKING } \\
\text { SENSATION) }\end{array}$ & 2 & 2 & 1 \\
\hline SLR Test & 2 & 2 & 1 \\
\hline
\end{tabular}

\section{DISCUSSION: -}

1. Gridhrasi, there is involvement of Vata, Asti \& Sandhi dosha. This disease is considered as Madhyam marga roga. ${ }^{[4]}$

2. Samanya chikitsa of Vatavyadhi is Snehan, Swedan and Basti. ${ }^{[5]}$

3. In this case we administered Katibasti with Bala tail and also Aampachak vati, Rasnaghan vati. Rasnaghan vati acts as Vatashamak. ${ }^{[6]}$

4. Katibasti considered as snigdha swedan. Katibasti used in diseases of the Kati region (i.e. Lumbosacral region), here warm oil was used in the procedure which pacify prakupit Vata dosha by its ushna and snigdha guna. So, it reduces pain in the Vataj Gridhrasi and it also lubricates the region and relax the surrounding muscles.

\section{CONCLUSION: -}

1) From this case study it has become clear that Katibasti with shaman chikitsa has effective role in the management of Gridhrasi.

2) The patient has gain significant improvement in symptoms and SLR angle in relatively after treatment.

\section{REFERENCES: -}

1. Vd. Y G Joshi, Charak Samhita, Vaidyamitra prakashan, $4^{\text {th }}$ edition, 2014, Chikitsasthan, Adhyay No 28, Shlok No 56-57, Page No 633.

2. Vd. Y G Joshi, Charak Samhita, Vaidyamitra prakashan, $4^{\text {th }}$ edition, 2014, Chikitsasthan, Adhyay No 28, Shlok No 148, Page No 645.

3. Vd. Y G Joshi, Charak Samhita, Vaidyamitra prakashan, $4^{\text {th }}$ edition, 2009, Sutrasthan, Adhyay No 20, Shlok No 11, Page No 262. 
4. Agnivesha, Charak Samhita, Revised by Charak and Drudhabala with the Ayurved Dipika comentry of Chakrapani Dutt, edited by Vd. Yadavji Trikamji Acharya, Chaukhamba Surbharati Prakashan, Varanasi, 2017, Sutrasthan, Adhyay No 11, Shlok No 48-49, Page No 177.

5. Agnivesha, Charak Samhita, Revised by Charak and Drudhabala with the Ayurved Dipika commentary of
Chakrapani Dutt, edited by Vd. Yadavji Trikamji Acharya, Chaukhamba Surbharati Prakashan, Varanasi, 2017, Sutrasthan, Adhyay No 25, Shlok No 40, Page No 132.

6. Bhavprakash Nighantu of Sri Bhavmisra, commentary by Dr K C Chunekar, edited by Dr G S Pandey, Chaukhambha Bharati Academy, Varanasi, $19^{\text {th }}$ edition, 1993, Haritakyadivarga, Shlok No 163-164, Page No 76. 